\title{
KLK6 wt Allele
}

National Cancer Institute

\section{Source}

National Cancer Institute. KLK6 wt Allele. NCI Thesaurus. Code C133890.

Human KLK6 wild-type allele is located in the vicinity of 19q13.41 and is approximately 11

$\mathrm{kb}$ in length. This allele, which encodes kallikrein- 6 protein, plays a role in post-

translational protein processing. 